\title{
PENINGKATAN PENGETAHUAN DAN PEMERIKSAAN SKABIES SANTRI PONDOK PESANTREN NURUL ISLAM SEKARBELA
}

\author{
Lalu Husnul Hidayat ${ }^{1}$, Siti Rahmatul Aini ${ }^{1}$, Dedianto Hidajat ${ }^{1}$, Iman Surya Pratama ${ }^{1}$ \\ 1 Universitas Mataram, Mataram, Indonesia \\ laluhusnul@gmail.com
}

\begin{abstract}
Abstrak: Angka prevalensi skabies di pondok pesantren di Indonesia adalah sebesar 3,9-6\% termasuk di Provinsi Nusa Tenggara Barat. Alih pengetahuan oleh tenaga kesehatan terdidik pada santri diperlukan untuk mencapai pesantren bebas skabies. Program pengabdian kepada masyarakat (PKM) ini bertujuan untuk menentukan peningkatan pengetahuan, status perilaku kebersihan santri dan kesehatan kulit santri melalui penyuluhan dan pemeriksaan skabies pada santri Madrasah Aliyah Nurul Islam Sekarbela, Kota Mataram. Peningkatan pengetahuan ditentukan melalui pemberian kuesioner pretest dan post-test setelah penyuluhan. Status perilaku kebersihan santri ditentukan melalui wawancara semi terstruktur. Status dermatologis ditentukan melalui penemuan lesi skabies dengan pemeriksaan fisik dan teknik dermoskopi. Penyuluhan yang telah dilakukan meningkatkan pengetahuan santri terkait skabies sebesar 25$90 \%$. Status perilaku kebersihan santri terkait skabies pada aspek kebersihan diri terkait penularan masih rendah dengan persentase lebih dari 50\%. Berdasarkan pemeriksaan fisik, sebesar $21 \%$ santri terinfeksi skabies ( $n=52$ orang) dengan status dermatologikus berupa papula, erilematosa, skuama, dan erosi.
\end{abstract}

Kata Kunci: alih pengetahuan, skabies, santri, madrasah

\begin{abstract}
The prevalence of scabies in Islamic boarding schools in Indonesia is 3,9-6\%, including the province of West Nusa Tenggara. A knowledge transfer by educated health workers to madrasa students (santri) is needed to protect boarding schools from scabies. This community service program aimed to elevate the students'knowledge of scabies, develop their hygiene behavior, and help them understand skin protection. It was done through counseling and physical examinations on students of MA Nurul Islam Sekarbela. The increase of knowledge was examined through the provision of pre and post counseling questionnaires. The personal hygiene status was determined through semi-structured interviews. Meanwhile, dermatological status was assessed through the scabies lesions by the physical examination and dermoscopy techniques. The counseling increased students'knowledge of scabies at $72 \%-95 \%$. The aspect of personal hygiene relating to transmissions is still low (> 50\%). Based on the physical examinations, $21 \%$ of the students were infected with scabies $(n=52)$ in the form of papules, erythematous, squama, and erosion.
\end{abstract}

Keywords: knowledge transfer, scabies, santri, madrasa

\section{Pendahuluan}

Angka prevalensi skabies di Puskesmas seluruh Indonesia pada tahun 2013 berkisar antara 3,9-6\% dan merupakan penyakit kulit terbanyak ketiga (Departemen Kesehatan RI, 2017). Demikian juga di provinsi Nusa Tenggara Barat berdasarkan angka prevalensi skabies pada tahun 2010 pada santriwati Pondok Pesantren Maraqi Ta'limat Wanasaba Kabupaten Lombok Timur sebesar 42\% erinfeksi skabies. Hasil studi Kurniawan, dkk (2019) menunjukkan angka prevalensi $60 \%$ santri terkena skabies di Pondok Pesantren MA Ishlahil Athfal Rumak Kabupaten Lombok Barat.

Kualitas hidup santri yang terinfestasi skabies akan terganggu akibat gatal hebat dan radang kulit akibat infeksi sekunder oleh bakteri. Produktivitas dan prestasi akademik santri 
dapat menurun akibat gejala yang ditimbulkan. Studi yang dilakukan oleh Merti, dkk (2019) menunjukkan terdapat korelasi positif antara infestasi skabies dengan tingkat konsentrasi dan prestasi belajar santri salah satu pondok pesantren di Bandar Lampung $(p<0.0001)$. Selain itu, penderita skabies dapat menjadi sumber infeksi bagi lingkungannya sehingga harus diobati.

Berdasarkan data Badan Pusat Statistik yang dilansir pada 16 November 2017, menyatakan bahwa penyakit kulit infeksi berada pada peringkat keenam dari 10 penyakit dengan jumlah kasus terbanyak di provinsi Nusa Tenggara Barat (Badan Pusat Statistik Prov. NTB, 2017). Skabies merupakan penyakit kulit infeksi akibat infestasi Sarcoptes scabiei var. hominis. Gejala yang timbul seperti lesi kulit pada daerah predileksi, pruritus nokturnal, dan riwayat sakit serupa dalam satu rumah merupakan diagnosa presumtif skabies. Diagnosis skabies dapat ditegakkan melalui keberadaan tungau, larva, telur atau kotoran melalui pemeriksaan mikroskopis (Perhimpunan Dokter Spesialis Kulit dan Kelamin Indonesia, 2017).

Kemiskinan, kepadatan penghuni rumah, tingkat pendidikan yang rendah, keterbatasan air bersih dan perilaku kebersihan yang buruk merupakan faktor penyebab angka prevalensi yang tinggi. Kepadatan penghuni merupakan faktor yang dominan sehingga angka prevalensi yang tinggi dapat ditemui di institusi padat penduduk seperti asrama, panti asuhan, penjara, pengungsian termasuk pondok pesantren hal ini ditunjang dengan perilaku hidup bersih dan sehat di pondok pesantren masih terbilang buruk (Sungkar, 2016).

Berdasarkan hal tersebut, pesantren perlu berbenah diri untuk menjadi institusi pendidikan yang bersih dan sehat agar terbebas dari skabies. Hal ini seiring dengan harapan Menteri Kesehatan Nila Moeloek dalam kunjungan ke Pesantren Cipasung Jawa Barat pada 27 Maret 2019 terkait pesantren bebas kudis berupa pengobatan kudis di posko kesehatan pesantren, pengawasan dan edukasi perilaku hidup sehat terhadap santri agar terbebas dari kudis (Kementerian Kesehatan, 2019). Alih pengetahuan tenaga kesehatan sebagai agen perubahan pada santri diperlukan di pondok pesantren (Sungkar, 2016).

Yayasan Nurul Islam Sekarbela merupakan sebuah yayasan yang bergerak di lingkungan pendidikan keagamaan terdiri dari 200 santri dan 150 santriwati. Yayasan ini telah menjadi salah satu mitra pengabdian sejak tahun 2016 (Aini, dkk. 2020; Pratama dkk. 2019). Berdasarkan informasi dari pimpinan pondok pesantren menuturkan ada beberapa santri yang sudah terinfeksi skabies walaupun pondok memiliki posko kesehatan. Pimpinan pondok pesantren juga menyatakan bahwa masih adanya kebiasaan santri yang dapat memicu penyakit skabies.

Alih pengetahuan oleh tenaga kesehatan, pemeriksaan perilaku kebersihan dan kesehatan kulit santri di Pondok Pesantren Nurul Islam hingga tahun 2019 belum pernah dilakukan. Oleh karena itu, tujuan pengabdian masyarakat kali ini yaitu menentukan peningkatan pengetahuan, status pola hidup bersih dan sehat (PHBS) dan dermatologis santri melalui penyuluhan dan pemeriksaan terkait skabies pada santri Madrasah Aliyah Pondok Pesantren Nurul Islam Sekarbela.

Program ini diharapkan mampu berkontribusi dalam memecahkan persoalan di masyarakat terlebih santri Madrasah Aliyah Pondok Pesantren Nurul Islam Sekarbela. Serta mampu mendorong pertumbuhan dan pembangunan sosial budaya masyarakat Nusa Tenggara 
Barat selaras dengan visi, misi, tujuan dan sasaran Program Studi Farmasi Fakultas Kedokteran Universitas Mataram.

\section{Metode}

Kegiatan pengabdian ini dilaksanakan dengan beberapa cara yang terdiri dari pemberian kuesioner pretest, proses penyuluhan, wawancara pola hidup bersih dan sehat, pemeriksaan dermatologi, dan pemberian kuesioner post-test. Pemberian kuesioner pretest dan post-test bertujuan untuk mengukur alih pengetahuan jangka pendek. Wawancara Perilaku Hidup Bersih dan Sehat (PHBS) bertujuan untuk memperoleh gambaran PHBS secara subjektif dari target. Adapun pemeriksaan fisik dilakukan untuk memastikan infeksi scabies dan status dermatologis sasaran kegiatan.

Kegiatan pretest merupakan langkah awal untuk menilai tingkat pengetahuan sasaran PPM terkait skabies. Pengerjaan soal pretest diberikan dalam jangka waktu 15 menit untuk setiap peserta kegiatan. Jawaban pretest kemudian dikumpulkan untuk dianalisa lebih lanjut oleh tim. Pada kegiatan postest dilakukan hal yang sama dengan kegiatan pretest, namun soal diberikan sesudah kegiatan penyuluhan.

Penyuluhan dilakukan dengan cara penyampaian materi skabies dengan metode ceramah menggunakan alat bantu LCD proyektor sebagai sarana pembelajaran. Narasumber berasal dari tim kegiatan. Setelah penyampaian materi, dilanjutkan dengan sesi diskusi berupa tanya jawab antara peserta dengan narasumber. Proses diskusi selain memberikan kesempatan bagi peserta untuk memperluas wawasan juga sebagai bagian konfirmasi terhadap penyuluhan yang diberikan

Setelah proses penyuluhan selesai dilanjutkan untuk kegiatan wawancara pola hidup bersih dan sehat dilakukan untuk memperoleh informasi kebiasan santri selama di pondok pesantren. Proses wawancara dilakukan kepada masing-masing peserta penyuluhan. Wawancara dilakukan kurang lebih selama 5 menit untuk masing - masing santri. Pemeriksaaan dilakukan pada setiap santri di ruangan pemeriksaan kesehatan pesantren. Status skabies dan dermatologi selanjutnya ditentukan berdasarkan pemeriksaan pakar (dokter spesialis kulit dan kelamin). Pemeriksaaan fisik dilakukan secara langsung oleh dokter spesialis dalam proses pengabdian.

Pengembangan instrumen pretest, post-test, pertanyaan wawancara pola hidup bersih dan sehat, serta daftar tilik pemeriksaan status skabies menggunakan butir soal yang dikembangkan dari Sungkar (2016). Data yang diperoleh dari seluruh tahapan kegiatan selanjutnya dianalisa secara deskriptif. Seluruh rangkaian kegiatan pengabdian yang dilakukan di pondok pesantren Nurul Islam Sekarbela ini diilustrasikan sebagaimana dalam gambar 1 dan 2. 


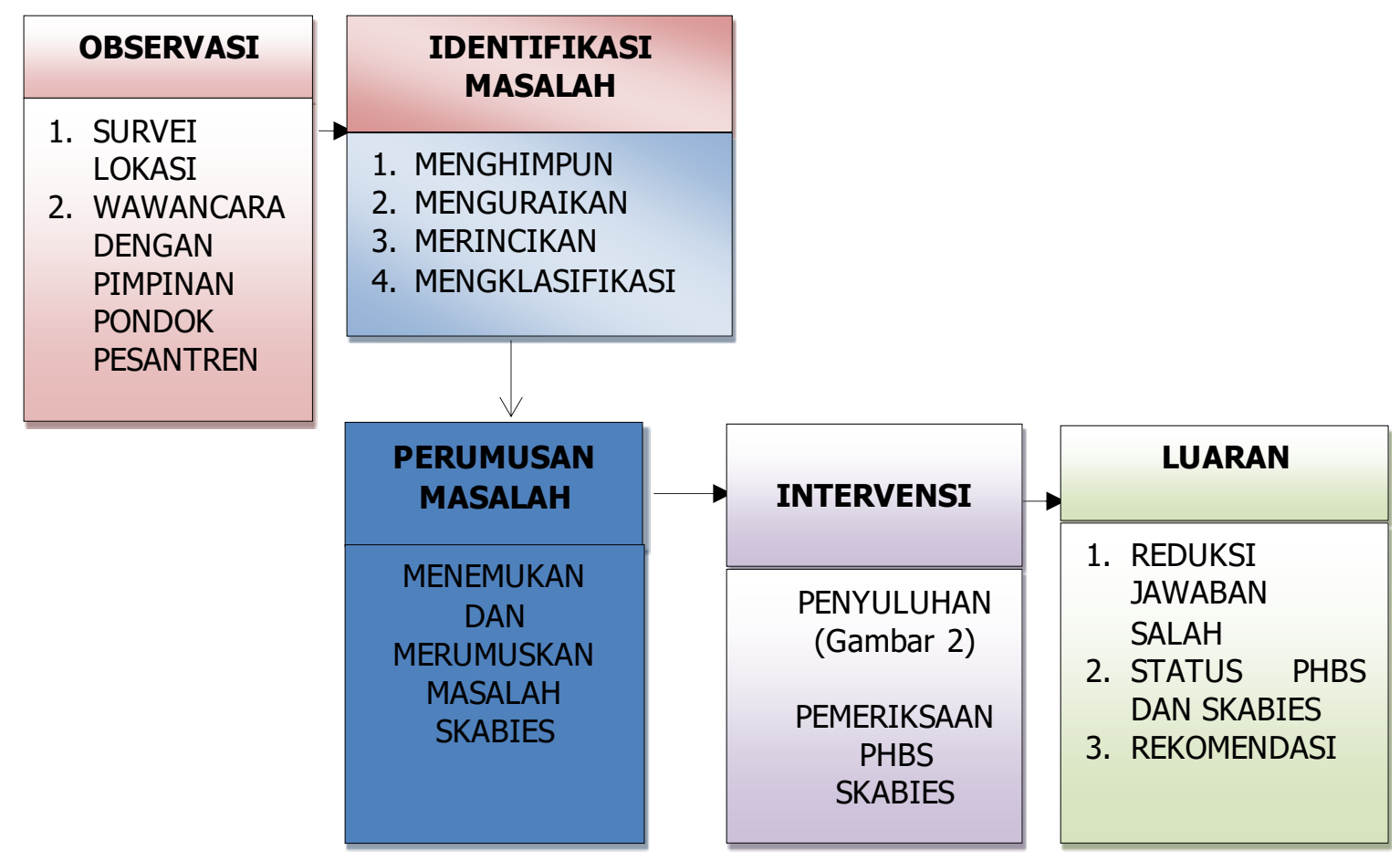

Gambar 1. Ilustrasi Alur metode Penelitian

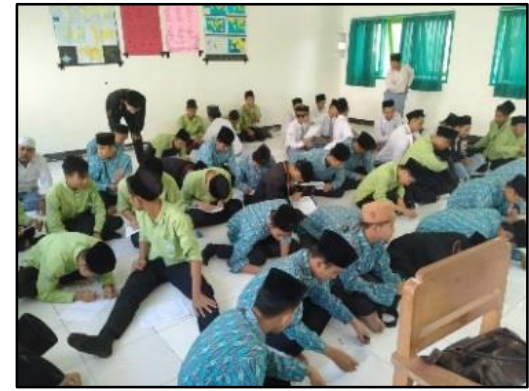

Pretest

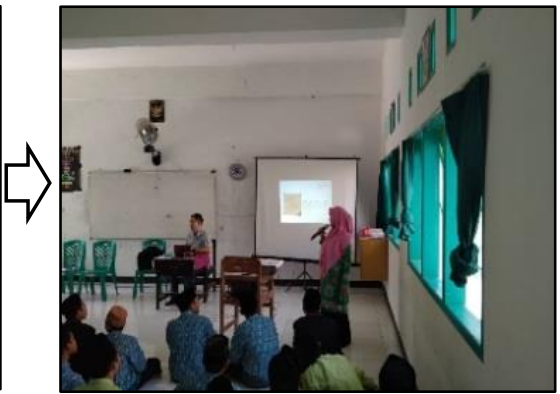

Penyuluhan

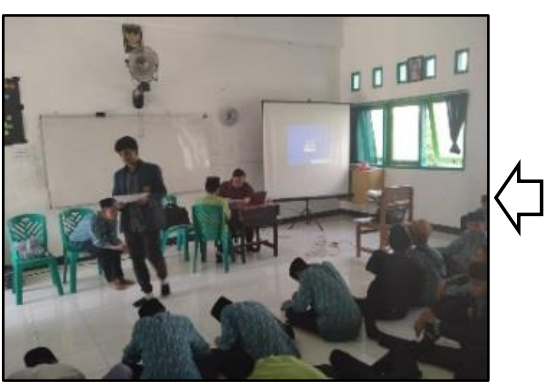

Post-test

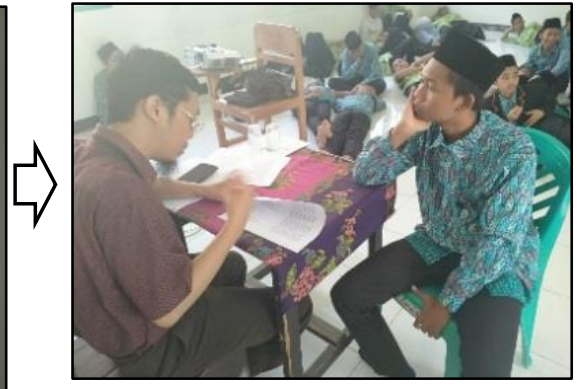

Wawancara

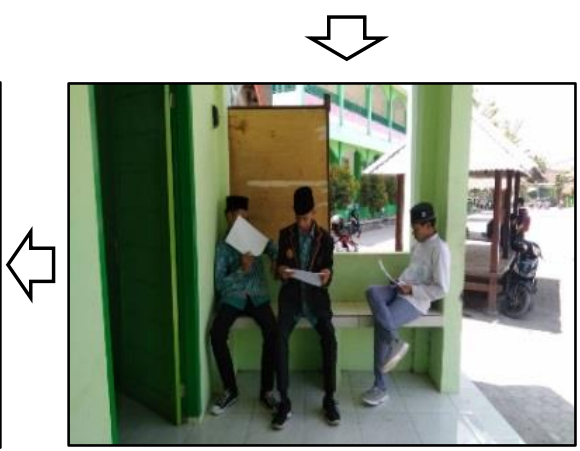

Pemeriksaan

Gambar 2. Ilustrasi proses penyuluhan kegiatan pengabdian 


\section{Hasil dan Pembahasan}

Kegiatan alih pengetahuan dan pemeriksaan kulit pada santri Madrasah Aliyah Nurul Islam tentang penyakit skabies dilaksanakan pada hari Kamis, 10 Oktober 2019 di Aula Pondok Pesantren Madrasah Aliyah Nurul Islam Dusun Karang Pule, Kecamatan Sekarbela, Nusa Tenggara Barat. Kegiatan ini melibatkan 2 orang guru beserta 52 santri yang terdiri dari 18 santri kelas X, 20 santri kelas XI, dan 14 santri kelas XII. Kegiatan meliputi survei pengetahuan dan sikap santri serta pemeriksaan terkait skabies.

Kegiatan dimulai dari pengisian kuesioner pretest oleh santri selama 15 menit yang bertujuan untuk menentukan pengetahuan santri. Kegiatan ini dilakukan sebelum dan setelah penyuluhan. Penyuluhan tentang materi skabies dilakukann dengan metode ceramah (30 menit) dan diskusi (15 menit). Untuk menentukan perilaku hidup bersih dan sehat santri terkait skabies dilakukan sesi wawancara terarah terdiri atas 10 pertanyaan selama 10 menit.

Hasil wawancara tentang status pola hidup bersih dan sehat terkait skabies diilustrasikan dalam gambar 3. Status pola hidup bersih dan sehat santri yang masih rendah meliputi aspek bertukar/saling meminjam pakaian, tidak mencuci pakaian secara rutin, tidak menyetrika dan tidur dalam satu kasur. Anggapan bahwa badan dan pakaian yang digunakan masih cukup bersih, malas untuk sering mencuci, tidak tersedia fasilitas setrika di pondok menjadi faktor faktor yang melatar belakangi perilaku tersebut.

Hal serupa juga ditemukani di studi yang dilakukan pondok pesantren An - Nasyath. Penggunaan pakaian pribadi secara bersama - sama seperti handuk, selimut, jaket, mukena, bahkan sabun mandi, padahal perilaku seperti itu dapat meningkatkan resiko infeksi skabies (Hilma dan Ghazali, 2014). Perilaku kebersihan dalam kehidupan sehari - hari berpengaruh bagi derajat kesehatan dan secara signifikan dapat mencegah berbagai penyakit termasuk skabies sehingga perlu ditingkatkan (Layya dan Nasaruddin, 2016).

Hal ini senada dengan hasil penelitian Pertiwi, dkk. (2017) mengenai faktor -faktor yang berhubungan dengan kejadian suspek skabies pada santri Pondok Pesantren Al - Aziziyah Kapek Gunung Sari tahun 2015. Dari 95,69\% suspek skabies (jumlah sampel 93 orang) dengan menggunakan analisis bivariat diperoleh perilaku kebersihan santri faktor kebersihan diri sebagai salahsatu faktor yang berpengaruh pada suspek skabies. Kelembapan, ventilasi, kepadatan hunian, dukungan pondok merupakan faktor lain yang mendukung kejadian suspek skabies.

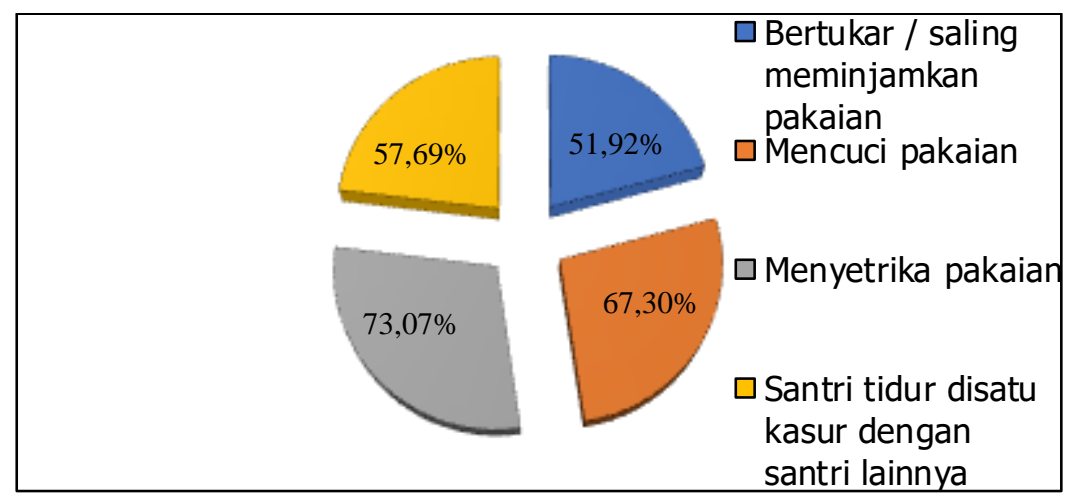

Gambar 3. Hasil wawancara perilaku kebersihan santri terkait skabies 
Pemeriksaan fisik meliputi lokasi lesi, luas lesi, dan status dermatologis dilakukan pascawawancara pada masing-masing santri di ruang Poskestren oleh dokter spesialis kulit. Diagnosa skabies ditentukan dengan adanya lesi pada daerah predileksi melalui pemeriksaan fisik dan teknik dermoskopi. Berdasarkan hasil pemeriksaan secara umum ditemukan $21 \%$ santri ( $n=11$ dari 52 santri) positif terinfeksi skabies. Lokasi lesi dominan terletak di punggung, lengan bawah, bokong, tangan atas, tangan bawah, dan sela jari dengan luas terbatas. Status dermatologikus santri terdiri dari papula, eritematosa, skuama dan erosi. Hasil pemeriksaan lesi skabies dapat ditunjukkan pada gambar 4.

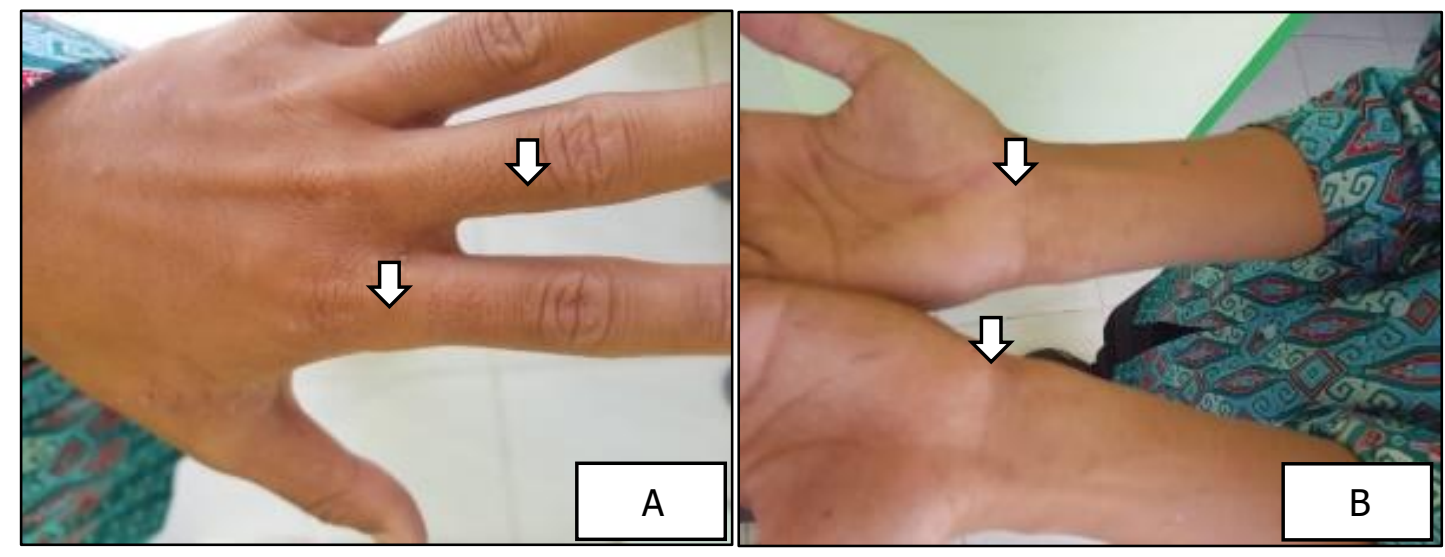

Gambar 4. Hasil pemeriksaan berupa lesi skabies pada santri

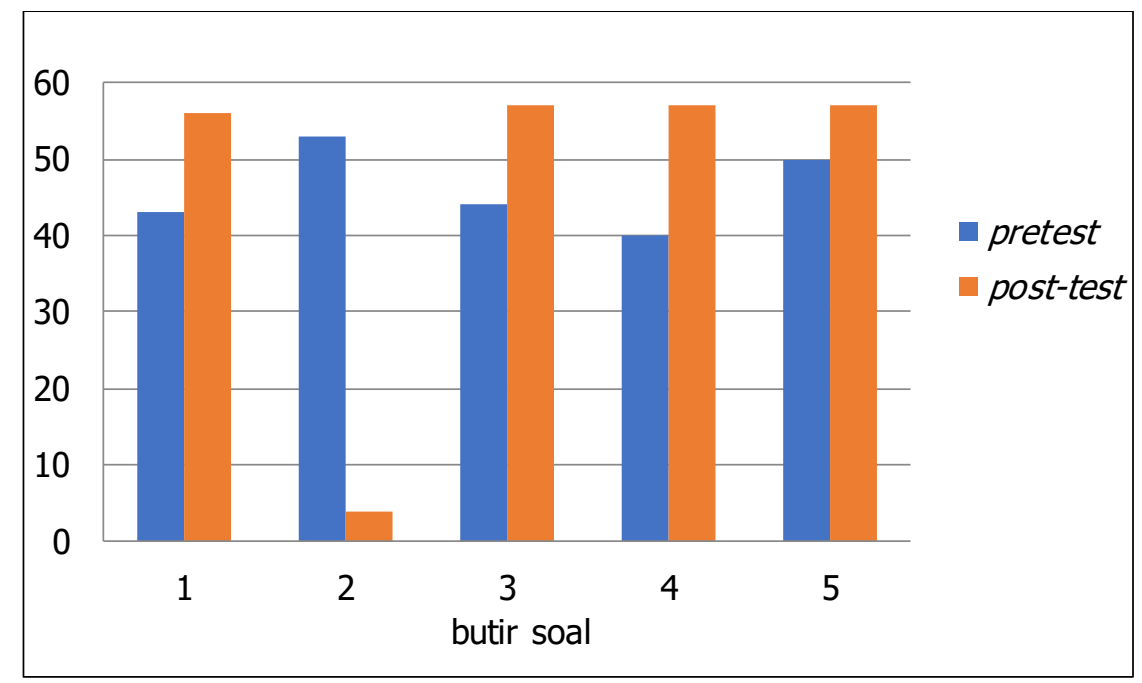

Gambar 5. Jawaban responden pada aspek pengetahuan umum santri terkait skabies. Keterangan butir soal : (1) terminologi medis (2) penyebab (3) agen kausal (4) lokasi hidup agen kausal (5) lokasi kembang biak

Aspek pengetahuan santri mengenai skabies ditentukan dengan menggunakan kuesioner. Aspek pengetahuan tersebut meliputi: pengetahuan umum, gejala klinis, pengobatan, penularan, dan pencegahan terkait skabies. Hasil pretest dan posttest pengetahuan santri dari sebelum dan sesudah penyuluhan dapat diilustrasikan pada gambar $5,6,7,8,9$. Secara umum terjadi alih pengetahuan santri pasca penyuluhan melalui peningkatan pengetahuan sebelum 
penyuluhan berkisar $25-90 \%$ pada setiap aspek ditunjukkan melalui penurunan jawaban yang salah oleh tiap responden.

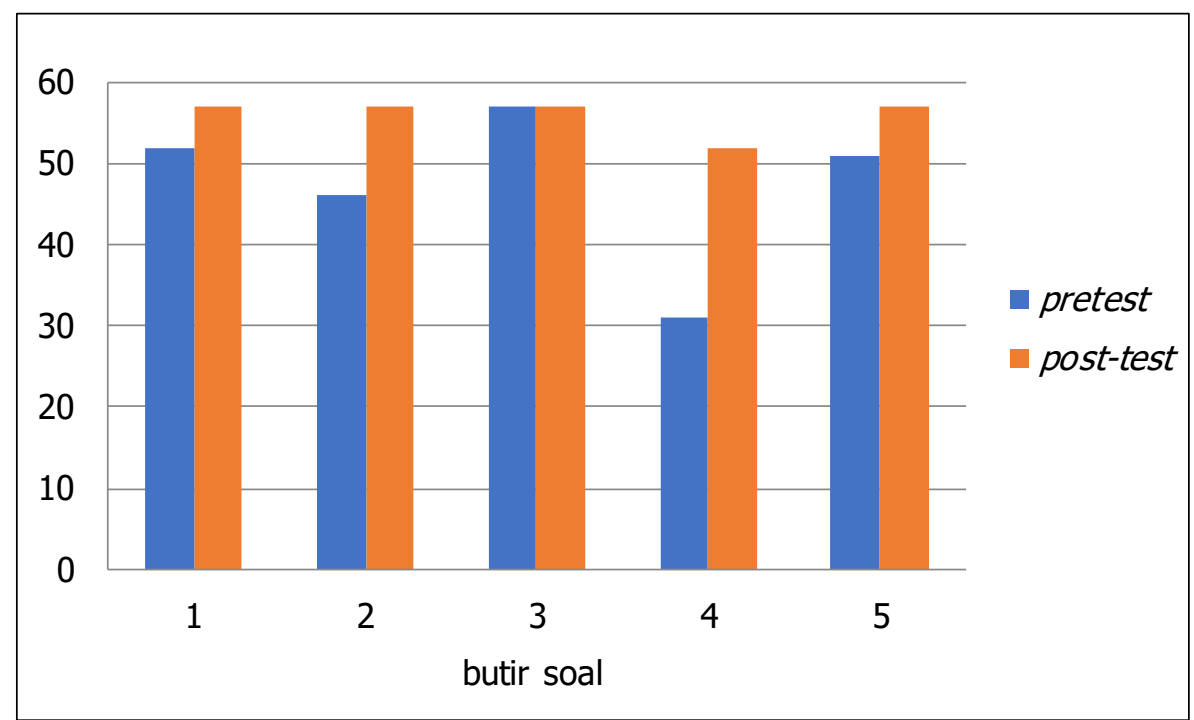

Gambar 6. Jawaban responden pada aspek gejala klinis skabies. Keterangan butir soal : (1) tanda dan gejala kulit (2) waktu rasa gatal (3) daerah koreng (4) gangguan selain kulit (5) lokasi yang sering ditemukan pasien.

Hasil pretest dan posttes untuk aspek pengetahuan umum dengan jawaban salah tertinggi diperoleh pada aspek penyebab skabies. Untuk aspek gejala klinis, santri masih belum mengetahui mengenai gejala skabies yang dialami selain gejala yang terdapat pada kulit. Hal ini mungkin disebabkan gejala yang paling umum dirasakan oleh santri adalah gejala kulit. Penekanan penyuluhan pada aspek gejala kulit juga dapat menyebabkan fokus santri pada aspek gejala kulit sebagai jawaban utama.

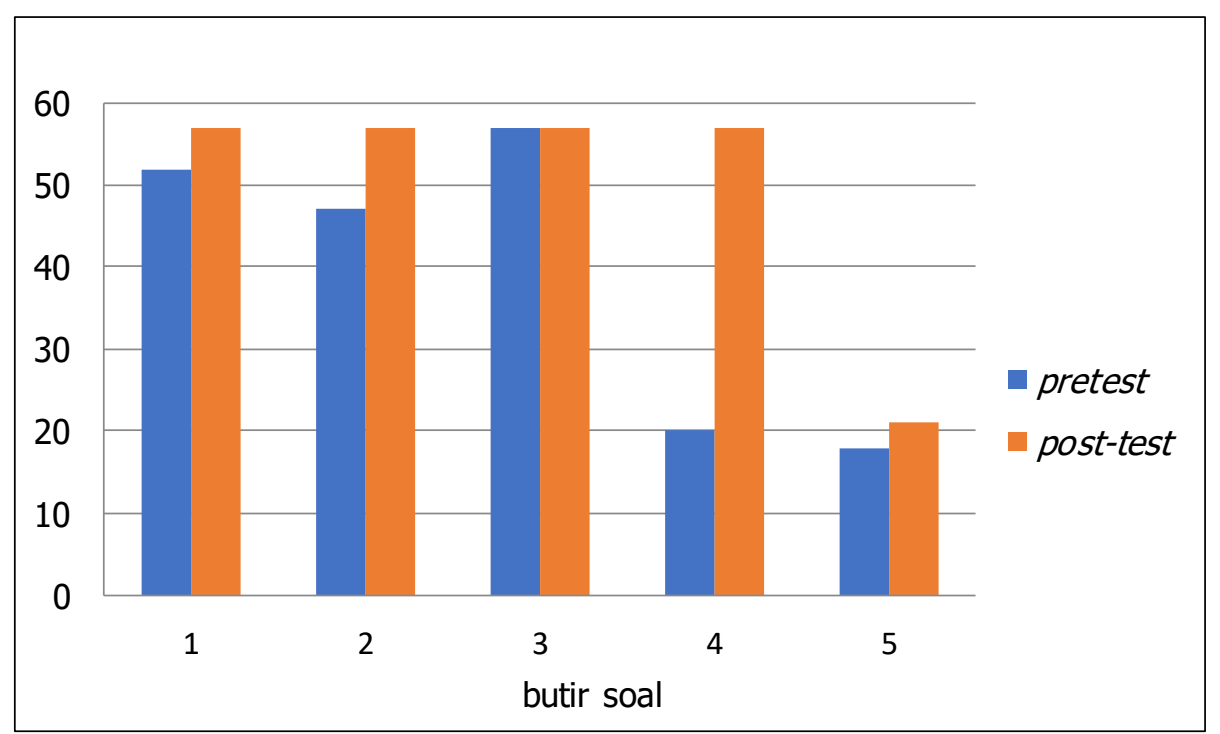

Gambar 7. Jawaban yang salah pada aspek pengobatan skabies. Keterangan butir soal : (1) alasan pengobatan pasien (2) jenis obat (3) cara menggunakan obat (4) pengulangan salep (5) pengobatan di asrama 


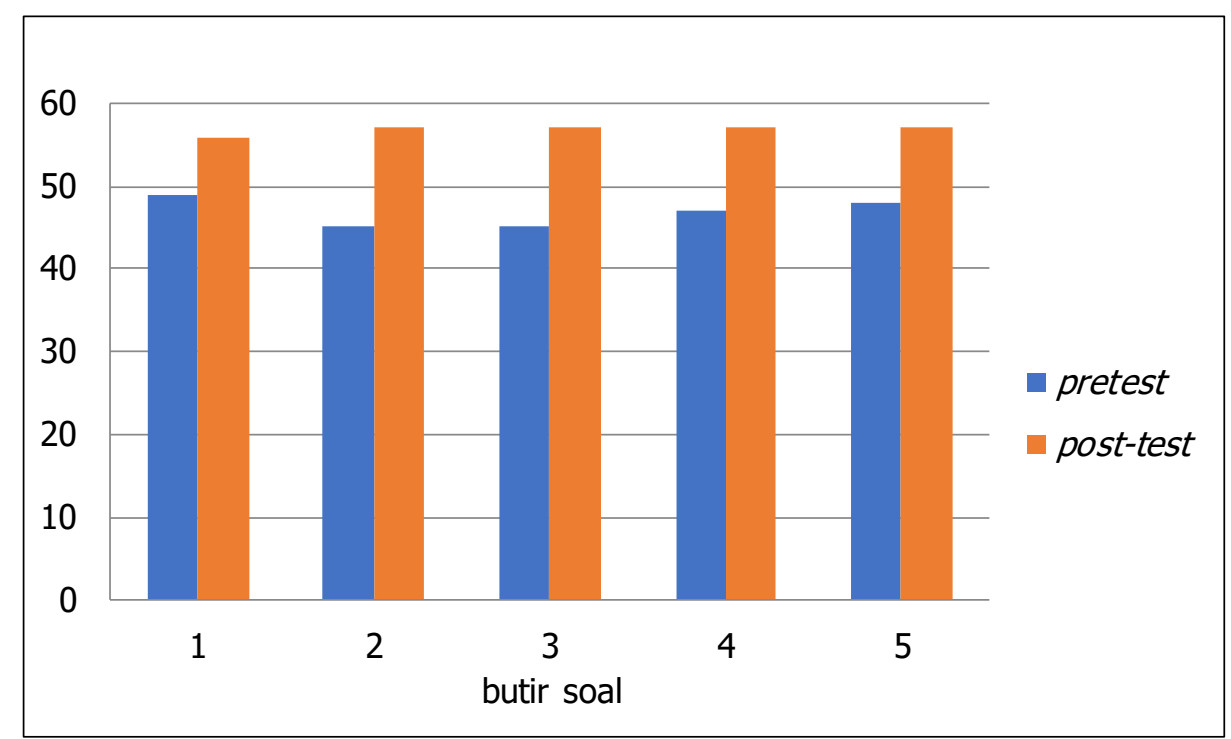

Gambar 8. Jawaban reponden pada aspek penularan skabies. Keterangan butir soal : (1) orang yang rentan tertular (2) cara penularan (3) barang pribadi penular (4) upaya proteksi (5) rute transmisi

Untuk aspek pengobatan, santri masih belum mengetahui penggunaan salep skabies secara berulang dan penggunaan obat secara masal. Hal ini selain diakibatkan ketidaktahuan santri, pihak pondok belum memfasilitasi pengobatan skabies secara masal sehingga santri terbiasa untuk mengobati secara mandiri bahkan tidak pernah melakukan pengobatan skabies. Pada aspek penularan, pengetahuan santri tentang cara penularan melalui barang pribadi masih rendah. Kebiasaan santri terkait pinjam meminjam pakaian dan tidur satu kasur dapat menjadi faktor resiko terjadinya skabies.

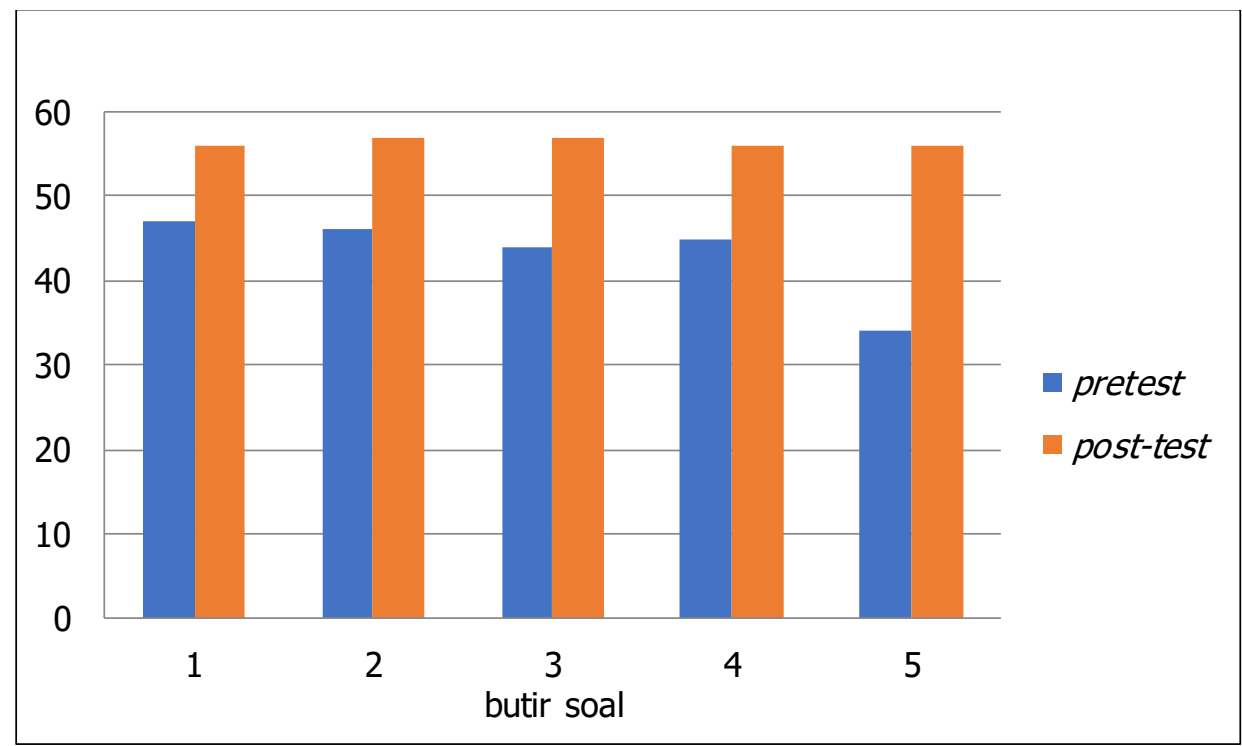

Gambar 9. Jawaban responden pada aspek pencegahan skabies. Keterangan butir soal: (1) pencegahan (2) tindakan (3) pencegahan wabah (4) sikap terhadap pasien (5) pengendalian ruangan 
Aspek pencegahan menjadi salah satu kendala yang hampir dialami oleh berbagai pesantren berupa aspek pengendalian skabies dalam ruangan. Hal ini disebabkan fasilitas pesantren berupa ventilasi udara, pencahayaan dan penerangan ruangan yang kurang baik. Hal sama juga terjadi pada pondok pesantren Darut Taqwa yang menunjukkan masih kurangnya fasilitas pondok, sehingga menjadi faktor penyebab terjadinya resiko skabies yang cukup tinggi (Putri, 2016).

Berdasarkan gambar 5, 6, 7, 8, 9 diatas menunjukkan perbaikan pengetahuan pascapenyuluhan untuk keseluruhan aspek. Pengetahuan santri pascapenyuluhan meningkat hampir keseluruhan ditinjau dari seluruh aspek dengan peningkat semula 25-90\% menjadi 70$90 \%$ dari jawaban yang diberikan. Pengetahuan menjadi faktor utama menjadi landasan seseorang dalam bertindak, setelah memiliki pengetahuan maka akan terbentuk sikap kesiapan atau kesediaan untuk terwujudnya suatu perilaku untuk berubah (Hilma dan Ghazali, 2014). Sebagaimana yang dinyatakan oleh Green (2005) dalam Detels, dkk. (2015) bahwa perilaku dibentuk oleh beberapa faktor salah satunya adalah pengetahuan yang termasuk dalam faktor predisposisi.

Dari hasil pengabdian kepada masyarakat yang telah dilakukan, rekomendasi tim pengabdian kepada pengelola yang dapat diimplementasikan secara sederhana di pondok pesantren adalah sebagai berikut: (1) tindakan pengobatan dilakukan terhadap santri yang terinfeksi skabies (2) tindakan pencegahan dapat dilakukan melalui minimalisasi pertukaran barang pribadi antar santri, dan (3) pemberdayaan POSKESTREN yang telah didirikan di lingkungan Yayasan Pomdok Pesantren Nurul Islam bekerja sama dengan Puskesmas Karang Pule.

\section{Kesimpulan}

Berdasarkan Program Pengabdian Kepada Masyarakat yang dilakukan dapat disimpulkan: 1) penyuluhan yang dilakukan telah meningkatkan pengetahuan santri terkait aspek umum, gejala, penularan, pengobatan dan pencegahan dari 25-90\% menjadi $70-90 \%, 2$ ) status perilaku kebersihan santri terkait skabies terkait penularan masih rendah ( $>50 \%)$, dan 3) Angka prevalensi skabies santri ( $n=52$ orang) pada tahun 2019 sebesar $21 \%$ dengan status dermatologikus berupa papula, eritematosa, skuama dan erosi.

\section{Ucapan Terima Kasih}

Ucapan terima kasih ditujukan kepada Lembaga Penelitian dan Pengabdian Kepada Masyarakat Universitas Mataram, Program Studi Farmasi Fakultas Kedokteran Universitas Mataram dan pondok pesantren Nurul Islam Sekarbela atas kerjasama sehingga Program Pengabdian Kepada Masyarakat dapat terselenggara. 


\section{Referensi}

Aini, S. R., Pratama, I. S., Ananto, A. D., \& Budiani. L. P. G. S. (2020). Workshop Pangan Jajanan Anak Sekolah (PJAS) dan Inovasi Sarapan Sehat untuk Anak Usia Sekolah. INDRA Jurnal Pengabdian Kepada Masyarakat. 1(1), 15-19

Badan Pusat Statistik Provinsi Nusa Tenggara Barat. (2017). Jumlah Kasus 10 Penyakit Terbanyak di Provinsi Nusa Tenggara Barat 2016, Diakses dari ntb.bps.go.id pada tanggal 30 November 2019.

Departemen Kesehatan Republik Indonesia. (2017). Pedoman Penyelenggaraan dan Pembinaan Pos Kesehatan Pesantren. Diakses di: http://perpustakaan.depkes.go.id pada tanggal 16 November 2020.

Detels, R., Gulliford, M., Karim, Q. A. \& Tan, C. C. (2015). Oxford Textbook of Global Public Health. Vol.1. Oxford University Press: Oxford.

Hilma, U. D. \& Ghazali, L. (2014). Faktor-Faktor Yang Mempengaruhi Kejadian Skabies Di Pondok Pesantren Mlangi Nogotirto Gamping Sleman Yogyakarta. Jurnal Kedokteran dan Kesehatan Indonesia (JKKI), 6(3), 148-157

Kementerian Kesehatan Republik Indonesia. (2019). Jangan Lagi Ada Mitoa Kudis di Antara Santri, Diakses dari http://depkes.go.id pada tanggal 30 November 2019.

Kurniawan, E., Aini, \& Rahmawati, S. (2019). Penyuluhan Penanganan Penyakit Skabies di Yayasan Pondok Pesantren MA Ishlahil Athfal, Rumak, Kabupaten Lombok Barat. Jurnal Pengabdian Magister Pendidikan IPA, 2(1), 22-24

Layya, I \& Nasaruddin. (2016). Perilaku Hidup Bersih dan Sehat (PHBS) Dalam Tatanan Rumah Tangga Berbasis Kerusakan Akibat Tsunami Di Wilayah Kota Banda Aceh. Jurnal IImu Kebencanaan, 3(1), 19-26.

Merti, L.G. I. A., Mutiara, H., Suwandi, J. F., \& Ayu, P. R. (2019). Hubungan Skabies Dengan Prestasi Belajar Pada Santri Pondok Pesantren di Bandar Lampung. Medula, 8(2), 76.

Perhimpunan Dokter Spesialis Kulit dan Kelamin Indonesia. (2017). Panduan Praktik Klinis Bagi Dokter Spesialis Kulit dan Kelamin di Indonesia. Perhimpunan Dokter Spesialis Kulit dan Kelamin Indonesia.

Pertiwi, A. M., Hapsari, Y., \& Affarah, W. S. (2017). Faktor-Faktor yang Berhubungan dengan Suspect Skabies pada Santri Pondok Pesantren Al-Aziziyah Kapek Gunung Sari Provinsi Nusa Tenggara Barat Tahun 2015. Jurnal Kedokteran UNRAM, 6(2)

Pratama, I.S., Aini, S. R., \& Maharani, B. F. (2019). Implementasi GASING (Gerakan Anti Stunting) Melalui PHBS dan Pemeriksaan Cacing. Jurnal Pendidikan dan Pengabdian Masyarakat, 2(1), 80-83

Putri, I.P.N., D.A., Wibowo, A., \& Nugraheni. (2016). Hubungan Tingkat Pengetahuan Santri Dengan Perilaku Pencegahan Skabies Di Pondok Pesantren Darut Taqwa Bulusan Semarang Tahun 2016. Jurnal Kedokteran Diponegoro, 5(4), 1064-1073

Sungkar, S. (2016). Skabies : Etiologi, Patogenesis, Pengobatan, Pemberantasan dan Pencegahan, Jakarta: Badan Penerbit Fakultas Kedokteran Universitas Indonesia. 